\title{
Research
}

Estimation of Daily Water Requirements for Potted

\section{Ornamental Crops}

\author{
C.D. Stanley ${ }^{1}$ and \\ B.K. Harbaugh ${ }^{2}$
}

Additional index words. evapotranspiration, crop water use

Summary. Methodology was developed to estimate water requirements for production of 20 different potted ornamental plant species with practical application for water conservation in commercial operations. Water requirement prediction equations were generated using pan evaporation to estimate evaporative demand along with plant canopy height and width and flower height as input variables. Coefficients of determination $\left(R^{2}\right)$ for the prediction equations among plant species ranged from 0.51 to 0.91 , with the lower values mostly associated with plant species with an open or less-uniform growth habit. Variation in water use among different cultivars of marigold also was associated with differences in cultivar growth habit. Estimation of the daily water requirements of potted Reiger begonia and

Gulf Coast Research and Education Center, IFAS, University of Florida, 5007 60th Street East, Bradenton, FL 34203. Florida Agricultural Experiment Station Journal Series no. R02490.

${ }^{1}$ Associate Professor of Soil and Water Science.

${ }^{2}$ Professor of Environmental Horticulture
Ficus benjamina using their developed prediction equations was compared to actual water use under common growing conditions to demonstrate the implementation of the method for plant species differing in growth habit.

$\mathrm{A}$ s concern for environmental issues increases, the management and protection of natural resources by users such as the horticultural industry have come under greater scrutiny. Conservation of water resources by ornamental producers can be accomplished through adoption of more-efficient irrigation systems in conjunction with improved management practices. Reducing potential water quality degradation involves minimizing the loss ofapplied agrichemicals from the treated area, and often is tied directly to water management. Proper irrigation scheduling to meet crop water requirements can be an important management practice aimed at achieving both conservation of water quantity and protection of water quality.

Estimation of crop water requirements can be achieved through use of direct methods, indirect methods, or the use ofsimulation models (Hatfield, 1990). Indirect methods generally employ theoretical and empirical means (including energy balance and statistical methods) to estimate evapotranspiration (ET). The use ofsimulation models involves complex computer algorithms to estimate water use based on actual physical and plant physiological processes. Direct methods involve physically measuring water use through water budgeting, lysimetric weighing of water consumption, or even heat flow measurement of xylem sap flow as a function of transpiration (Cohen et al., 1987). To be successful, the prac- tical use of any method for estimating crop water requirements must account for plant species, stage and size of development, and environmental growing conditions. Many models use intensive measurement of both environmental conditions (temperature, humidity, light energy, air speed, etc.) and plant characteristics (leafarea, fresh weight, leaf water potential, diffusion resistance, etc.), which may include techniques that are destructive to the plants being measured in order to account for all the variables needed to estimate water requirements (Norman and Campbell, 1983). Most commercial producers do not have instrumentation, technical expertise, or personnel (hours) to use such models.

The objectives of this study were to: 1) develop a simple, usable means to estimate water-use requirements for selected potted ornamental crops; 2) determine differences in the ability of the prediction equations to estimate water use among selected ornamental plant species; and 3) identify limitations involved with implementation of the methodology.

A method of direct measurement (Stanley and Harbaugh, 1981) was used to determine actual water use by selected potted ornamental plant species (Table 1) during a 24 -h period and to compare this water use to the evaporative demand occurring during the same growing period. This method uses a capillary-mat irrigation system to maintain the experimental units at optimum soil moisture prior to and after water-use measurements. For each period ofwater-use determination, six potted plants were removed from the capillary mat, weighed on an electronic balance, and placed on a non-irrigated bench spaced according to plant species requirements. Measurements of canopy height and width and flower height for each plant were made immediately after placement, then each set of plants was left undisturbed for a 24-h period. At the end of 24-h, the plants were reweighed individually and placed back on the capillary mat, another set of six plants was removed, and the procedure was repeated. Each set of plants was used only once per week for water-use determinations. The use of this method effectively treated the individual pots as small weighing lysimeters, with water use determined by a water-balance method. Evaporative demand was estimated simulta- 
Table 1. Plant species name (common and scientific) and corresponding range of plant height $(\mathrm{PH})$, plant width $(\mathrm{PW})$, and pan evaporation $(E)$ measured and used togenerate water requirement estimation equations.

\begin{tabular}{|c|c|c|c|c|}
\hline \multirow[b]{2}{*}{ Common name } & \multirow[b]{2}{*}{ Scientific name } & \multicolumn{3}{|c|}{ Data collection ranges } \\
\hline & & $\mathrm{PH}(\mathrm{cm})$ & $\mathrm{PW}(\mathrm{cm})$ & $\mathrm{E}(\mathrm{mm} /$ day $)$ \\
\hline \multicolumn{5}{|c|}{ Flowering plants } \\
\hline Chrysanthenum & Dendranthemum grandiflora & $11-48$ & $24-60$ & $0.8 \quad 6.2$ \\
\hline Cyclamen & Cyclamen persicum & $4-16$ & $11-30$ & $2.0-5.1$ \\
\hline Exacum & Exacum affine & $9-42$ & $12-49$ & $0.6-3.8$ \\
\hline Hibiscus & Hibiscus rosa-sinensis & $29-65$ & $27-65$ & $1.1-3.4$ \\
\hline Poinsettia & Euploorbia pulcherrima & $8-49$ & $20-70$ & $0.6-3.2$ \\
\hline Reiger begonia & Begonia $\times$ biemalis & $2-29$ & $6-36$ & $0.6-6.4$ \\
\hline Shasta daisy & Chrysanthemum maximum & $6-32$ & $17-62$ & $1.0-4.4$ \\
\hline \multicolumn{5}{|c|}{$\begin{array}{l}\text { Foliage plants } \\
\end{array}$} \\
\hline Caladium & Caladium hortulanum & $2-82$ & $1-101$ & $0.8-3.4$ \\
\hline Dracaena & Dracaena marginata & $11-29$ & $46-83$ & $0.4-5.1$ \\
\hline Ficus & Ficus benjamina & $32-111$ & $50-110$ & $1.1-3.4$ \\
\hline Parlor palm & Chamaedorea elegans & $37-76$ & $15-65$ & $1.0-3.4$ \\
\hline Schefflera & Brassaia actinophylla & $31-93$ & $43-94$ & $0.4-5.1$ \\
\hline Asparagus fern & Asparagus sprengeri & $9-30$ & $12-44$ & $0.6-6.6$ \\
\hline \multicolumn{5}{|c|}{ Bedding plants } \\
\hline Celosia & Celosia plumosa & $4-23$ & $8-37$ & $1.0-5.8$ \\
\hline Coleus & Coleus $\mathrm{x}$ bybridus & $4-34$ & $8-47$ & $0.6-5.8$ \\
\hline Dianthus & Dianthus chinensis & $6-29$ & $7-33$ & $1.0-5.8$ \\
\hline Imaptiens & Impatiens wallerana & $5-26$ & $6-53$ & $0.6-6.6$ \\
\hline Marigold & Tagetes patula and T. erecta & $4-51$ & $7-40$ & $0.4-4.8$ \\
\hline Petunia & Petunia bybrida & $2-35$ & $8-40$ & $0.6-3.4$ \\
\hline Zinnia & Zinnia elegans & $4-64$ & $16-34$ & $0.5-4.8$ \\
\hline
\end{tabular}

neously using a Belfort Evaporation Recorder Model 6075 located in the same growing area as the plants used for this study. This instrument had a $250-\mathrm{cm}^{2}$ evaporation pan with a 24-h clock and, thus, afforded a continuous record of amount and rate of pan evaporation.

Plant species chosen for the study included those from flowering, foliage, and bedding plant groups (Table 1). Differences within a plant species were evaluated using six cultivars ofmarigold (Tagetes patula and T. erecta) that varied in growth habit. Selected cultivar types included: dwarf African (Cupid Orange and Pineapple Crush ); intermediate French ( Honeycomb and Midas Touch ); and tall African (Cracker Jack and Toreador ).

Data collected during this study were analyzed by a stepwise multipleregression technique (SAS Institute Inc., 1985). This method allowed addition or substitution of potential independent variables in the model to observe changes in statistical significance and improvement in the coeffcient of determination $\left(R^{2}\right)$ for each model. The postulated regression model was:

$$
\mathrm{W}=f(\mathrm{PH}, \mathrm{PW}, \mathrm{FH}, \mathrm{E}) \quad[\mathrm{Eq} .1]
$$

where $\mathrm{W}=$ total daily water use $(\mathrm{ml})$, $\mathrm{PH}=$ plant canopy height $(\mathrm{cm}), \mathrm{PW}=$ plant canopy width $(\mathrm{cm}), \mathrm{FH}=$ flower height $(\mathrm{cm})$, and $\mathrm{E}=$ daily pan evaporation $(\mathrm{mm})$.

Regression analyses were performed for each variable as linear and quadratic components as well as combinations (such as $\mathrm{PW}^{*} \mathrm{PH}$ ) and were entered into the model as individual variables. $\mathrm{PH}, \mathrm{PW}$, and $\mathrm{FH}$ were found to be significant for both linear and quadratic terms for some plant species. However, only linear terms of each were used in the final equations because addition of quadratic terms did not significantly improve the $R^{2}$, and our primary objective was to develop a simplified and practical prediction equation. The parameters included in the equations $(\mathrm{PH}, \mathrm{PW}, \mathrm{FH}$, or $\mathrm{E})$ were selected based on the best combination of $\mathrm{F}$ value and $R^{2}$.

Because the regression equation used to estimate daily water requirement for each plant species is only valid for the range of data for which it was developed, the data ranges for $\mathrm{PH}$, PW, and E are presented in Table 1. The majority of the flowering and bedding plant evaluations were initiated at the transplant stage (exception was hibiscus). The differences in pan evaporation for each plant species reflect the time of year that evaluations were made, length of production period, and growing environment (glass greenhouse, shadehouse, or completely exposed) where the crops were grown. In order to increase the range of evaporative demand conditions that the plants experienced, some crops were grown in more than one growing environment.

Table 2 contains the final regression equations for estimating water requirements for each of the plant species. All of these equations were statistically significant $(\mathrm{P}<0.01)$. Overall, the flowering plant group tended to have the highest $R^{2}$ values, averaging 0.82 , with the foliage group having the lowest, averaging 0.67. This can be attributed to the within-group variability in growth habit. The foliage group tended to have a higher degree of variation for canopy height and width, with fewer but larger leaves, and an open canopy. The flowering group and, in general, the bedding plant group, tended to have a more predictable, closed, and uniform plant canopy.

Verification of the usability of the prediction equations for chrysanthemum and poinsettia were reported (Stanley and Harbaugh, 1984,1989). Irrigation was scheduled for crop production using the developed daily water requirement equations and estimated water needs were compared to actual water use during the same growing period. The predicted daily water use amounts were plotted against measured water use and were in general agreement, except for a tendency to underestimate water needs during periods of high demand. This tendency was true for both plant species.

The results presented in Fig. 1 for two diverse species (Reiger begonia and $F$. benjamina) illustrate the comparison of actual vs. predicted water use. The $R^{2}$ of the prediction equations for Reiger begonia and F. benjamina were 0.84 and 0.59 , respectively. A similar relationship as that reported for chrysanthemum and poinsettia (Stanley and Harbaugh, 1984, 1989) was observed for Reiger begonia in that, for the most part, the prediction equation performed well although there was still a tendency to 
Table 2. Regression equations to estimate daily water requirements for selected potted ornamental crops.

\begin{tabular}{|c|c|c|}
\hline Plant species & Regression equation" & $R^{2}$ \\
\hline \multicolumn{3}{|c|}{ Flowering plants } \\
\hline Chrysanthemum & $W=-456.72+15.19(\mathrm{PH})+146.08(\mathrm{E})$ & 0.85 \\
\hline Cyclamen & $W=-15.67+2.05(\mathrm{PH})+0.76(\mathrm{PW})+0.61(\mathrm{FH})+7.89(\mathrm{E}$ & 0.79 \\
\hline Exacum & $W=-149.34+8.03(\mathrm{PH})+31.56(\mathrm{E})$ & 0.88 \\
\hline Hibiscus & $W=-109.42+3.82(\mathrm{PH})+48.01(\mathrm{E})$ & 0.76 \\
\hline Poinsettia & $W=-118.01+2.31(\mathrm{PH})+1.78(\mathrm{PW})+58.21(\mathrm{E})$ & 0.78 \\
\hline Reiger begonia & $W=-73.46+5.72(\mathrm{PH})+33.56(\mathrm{E})$ & 0.84 \\
\hline Shasta daisy & $W=-234.65-4.00(\mathrm{PH})+9.27(\mathrm{PW})+41.23(\mathrm{E})$ & 0.82 \\
\hline \multicolumn{3}{|c|}{ Foliage plants } \\
\hline Caladium & $W=120.49+3.27(\mathrm{PW})+30.70(\mathrm{E})$ & 0.61 \\
\hline Dracaena & $W=-177.19+5.24(\mathrm{PH})+1.58(\mathrm{PW})+20.33(\mathrm{E})$ & 0.81 \\
\hline Ficus & $W=-207.14+3.23(\mathrm{PH})+0.95(\mathrm{PW})+67.39(\mathrm{E})$ & 0.59 \\
\hline Parlor palm & $W=-28.92+0.94(\mathrm{PW})+18.94(\mathrm{E})$ & 0.51 \\
\hline Schefflera & $\mathrm{W}=-446.43+7.14(\mathrm{PH})+1.54(\mathrm{PW})+84.72(\mathrm{E})$ & 0.86 \\
\hline Asparagus fern & $W=-27.06+3.15(\mathrm{PH})+2.92(\mathrm{PW})+7.63(\mathrm{E})$ & 0.65 \\
\hline \multicolumn{3}{|c|}{ Bedding plants } \\
\hline Celosia & $W=-45.72+0.48(\mathrm{PH})+2.35(\mathrm{PW})+18.78(\mathrm{E})$ & 0.70 \\
\hline Coleus & $\mathrm{W}=-56.80+2.67(\mathrm{PH})+2.12(\mathrm{PW})+17.53(\mathrm{E})$ & 0.80 \\
\hline Dianthus & $W=-47.33+1.32(\mathrm{PH})+2.90(\mathrm{PW})+15.44(\mathrm{E})$ & 0.66 \\
\hline Impatiens & $\mathrm{W}=-70.77+2.10(\mathrm{PH})+2.31(\mathrm{PW})+24.07(\mathrm{E})$ & 0.74 \\
\hline \multicolumn{3}{|l|}{ Marigold } \\
\hline 'Cupid Orange' & $W=-42.37+3.97(\mathrm{PH})+0.76(\mathrm{PW})+14.50(\mathrm{E})$ & 0.75 \\
\hline 'Pineapple Crush' & $W=-39.15+2.43(\mathrm{PH})+1.90(\mathrm{PW})+13.77(\mathrm{E})$ & 0.82 \\
\hline 'Honeycomb' & $\mathrm{W}=-76.78+0.41(\mathrm{PH})+5.24(\mathrm{PW})+17.83(\mathrm{E})$ & 0.83 \\
\hline 'Midas Touch' & $W=-50.43+3.32(\mathrm{PH})+2.02(\mathrm{PW})+12.83(\mathrm{E})$ & 0.88 \\
\hline 'Cracker Jack' & $\mathrm{W}=-98.70+2.44(\mathrm{PH})+2.42(\mathrm{PW})+24.81(\mathrm{E})$ & 0.80 \\
\hline 'Toreador' & $W=-120.36+4.51(P H)+1.30(P W)+25.10(E)$ & 0.91 \\
\hline (combined) & $W=-61.37+2.85(\mathrm{PH})+2.33(\mathrm{PW})+16.08(\mathrm{E})$ & 0.80 \\
\hline Petunia & $\mathrm{W}=-31.90+4.92(\mathrm{PH})+11.32(\mathrm{E})$ & 0.71 \\
\hline Zinnia & $\mathrm{W}=-82.45+1.24(\mathrm{PH})+4.24(\mathrm{PW})+18.85(\mathrm{E})$ & 0.71 \\
\hline
\end{tabular}

${ }^{z} W=$ estimated daily water requirement $(\mathrm{ml}) ; \mathrm{PH}=$ plant canopy height $(\mathrm{cm}) ; \mathrm{PW}=$ plant canopy width $(\mathrm{cm}) ; F H=$ flower height $(\mathrm{cm}) ;$ and $E=$ daily pan evaporation $(\mathrm{mm})$.
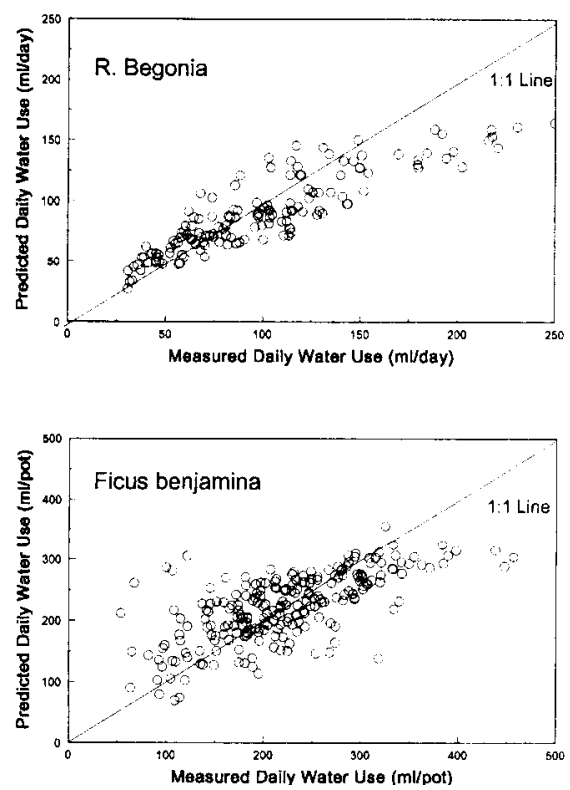

Fig.1. Measured daily water use vs. estimated water use determined from the respective developed water requirement estimation equations for Reiger begonia and F. benjamina (Table 2). underestimate water use during periods of high evaporative demand when the crop canopy was full. The results for $F$. benjamina show a less-acceptable relationship for this plant species, reflecting the low $R^{2}$ for the prediction equation.

The results from the evaluation of the marigold cultivars revealed that, within a plant species, there may be a need to account for the effect of diverse plant growth habit on water use. Although the regression equations to predict daily water requirements for all marigold cultivars had high $R^{2}$ values, the equation coefficients and intercept values varied among cultivars. These results indicate that perhaps additional evaluation of the water requirement differences of cultivars within a plant species is needed before a general equation is used, especially if there is a diverse range in plant canopy or growth characteristics.

In conclusion, we demonstrated that daily water requirements could be estimated with rather simple methodology using pan evaporation, plant height, and plant width. The method was useful for potted ornamental plant species chosen from bedding, foliage, and flowering plant types. Although regression prediction equations for some plant species resulted in higher coefficients of determination than others, in general, plant species with a more uniform, closed canopy responded more favorable. Similarly, results for plant cultivars within a species varied with growth habit. Because there arc many growing conditions outside the ranges experienced in this study, and there arc different cultivars of the plant species that may be grown, these results may need to be expanded to fit the crops and growing conditions in other locations. The outcome of this stud) satisfied the objective ofdeveloping a simplified (grower-friendly) method for estimating daily water requirements.

\section{Literature Cited}

Cohen, Y.M., M. Fuchs, V. Falkenburg and S. Moreshet. 1987. Calibrated heat pulse method for determining water uptake in cotton. Agron. J. 80:398-402.

Hatfield, J.L. 1990. Methods ofestimating evapotranspiration, p. 435474. In: B.A. Stewart and D.R. Neilsen (eds.). Irrigation of agricultural crops. ASA-CSSA-SSSA, Madison, Wis. Agronomy no. 30.

Norman, J.M. and G. Campbell. 1983. Application of a plant--environment model to problems in irrigation, p. 155-158. In: Daniel Hillel (ed.). Advances in irrigation. vol. 2. Academic, New York.

SAS Institute Inc. 1985. SAS user s guide: Statistics. 5th cd. SAS Institute Inc., Gary, N.C.

Stanley, C.D. and B.K. Harbaugh. 1981. A rapid and simple method for determining evapotranspiration requirements for potted ornamental crops. Proc. Fla. State Hart. Soc. 94:83-85.

Stanley, C.D. and B.K. Harbaugh 1984. Estimating daily water use for potted chrysanthemum using pan evaporation and plant height. HortScience 19:287-288.

Stanley, C.D. and B.K. Harbaugh. 1989. Poinsettia irrigation based on evaporative demand and plant growth characteristics. HortScience 24:937-939, 